\title{
Mathematics for Young Children: A Literature Review
}

\author{
Fauziah Rahmat \\ Universitas Pendidikan Indonesia, Jl. Setiabudhi 229, Bandung, Indonesia \\ Corresponding e-mail: fauziahrahmat@rocketmail.com
}

\begin{abstract}
A lot of researches have been conducted to identify the importance of mathematics and its benefits for the early childhood. To the contrary, there also emerge concerns about the risk of premature mathematics learning of the young children. In Indonesia, it appears that early childhood education is not yet designed to be a place to give academic study such as mathematics. Meanwhile, most of the research findings in other countries show that both the children's capacity and capability in learning mathematics and the confining policy, directly or indirectly, may have impacts on the instructional practice of mathematics in early childhood education. This article would like to discuss how literature reveals mathematics learning for early childhood through the role of the teacher.
\end{abstract}

Keywords: mathematics learning, early childhood, review

\section{INTRODUCTION}

Mathematics or math is considered difficult in concept (Ruseffendi, 2006) and more abstract than other subjects (Rutunkahu \& Kandou, 2014). Therefore though a lot of researchers in the last ten years break the notion that young children are not ready yet to learn math (Anthony \& Walshaw, 2009; Douglas H Clements \& Sarama, 2011; Douglas H. Clements \& Sarama, 2014a, 2014b; Dağlı \& Halat, 2016; Ginsburg, 2008; Mix, Prather, Smith, \& Stockton, 2014; Ramos-Christian, Schleser, \& Varn, 2008; Suyadi, 2014; Varol \& Farran, 2006), practically there occurs the impression that learning math for early childhood should be avoided.

In Indonesia, this issue is presented in the form of impetus for any academic study to be limited into the introductory and is not to be given until the children are ready (Government Circular No. 1839/C.C2/TU/2009 on the Implementation of Education in Kindergartens and New Student Admission of Elementary School, 2009; Government Circular No. 2519/C.C2.1/DU/2015 on the Implementation of Early Childhood Education, 2015). Moreover, the issues about the risk that interferes and threatens in case the children get premature academic study keep blowing (Safitri, 2013; Yuwanto, 2010) (Safitri, 2013; Yuwanto,
2010). In the other side, a number of research findings emphasize how crucial mathematics is and its benefits to children of early ages (Brendefur et al., 2015; Cross, Woods, Schweingruber, National Research, \& Committee on Early Childhood, 2009; Geary, 2013; Knaus, 2013; Notari-Syverson \& Sadler, 2008).

Therefore no wonder that pros and cons are still found in the learning of mathematics for early childhood, because historically, learning mathematics is considered unimportant and not appropriate for children of early age (Newton \& Alexander, 2013). According to Stipek (2013), mathematics learning for early childhood will always draw pros and cons. Thus in a situation where academic research supports on the one hand, yet the policy limits it in the other one, it is interesting to find out how teachers can play their role in the learning of mathematics for early childhood. This article seeks to discuss the issue.

\section{EARLY CHILDHOOD MATHEMATICS LEARNING}

According to van Oers (2010), a child's mathematical thinking is acquired from a cultural process. This cultural process includes the child's 
learning phase of understanding their own behaviors. They get to know their own behavior meanings by resolving their problems collaboratively with other people who are more knowledgeable in particular contexts. In specific, Brandt (2013) said that the concepts of math in children are developed through learning practices carried out by teachers.

The young learners are able to learn mathematics by integrating its concepts into their daily lives (Dobbs, Doctoroff, \& Fisher, 2003; K.W., 2011). As it stands, math is a science of logicmathematical (Kamii, 2014, 2016). Thus, the children are thought to be challenged through some activities. Those activities should require them to think; to solve the problems through physical activities in which entail a higher level of thinking. By having those intellectual challenges applied to the children, they would eventually obtain a vast and solid mathematical and logical thinking (Kirkland, Manning, Osaki, \& Hicks, 2015; Whitebread \& Coltman, 2015).

In spite of that, their experience gained from a child's play and pedagogical orientations are the perfect matches in children's mathematical learning. Kotsopoulos, Makosz, Zambrzycka, and McCarthy (2015) argued that the development of mathematical concepts in young learners would not be adequate should their playing experience occur without an explicit pedagogy.

In this regard, the teachers' ability to fit in the lesson and children's competence are the utmost importance. Moreover, based on Vygotsky's concepts, several developments: cognitive, social, or language are not inherently formed as a result of maturity; it is what they learn instead (Bodrova \& Leong, 2011).

It is generally conceived that the child's play is the most efficient approach for the young learners, as well as the mathematics (Tucker, 2013; Wortham, 2006). Therefore, the teachers of young learners are urged to have their own mathematical understanding that would enable them to understand and sustain their mathematical knowledge shown by the young learners within their holistic-recreational surroundings (Dunekacke, Jenßen, \& Blömeke, 2015; Haynes, 2000). It is that because the children have an informal mathematical asset which is not as simple as it is distinct to be accessed (Cross et al., 2009; Lee, 2014).

In the playing-learning-based frame, the teachers are obliged to create such positive surroundings for children to explore and develop their mathematical ability. Be that it is by establishing playing properties (Douglas $\mathrm{H}$. Clements \& Sarama, 2014b; Scarlatos, 2006); serving a specific mathematical activities (Brendefur, Strother, Thiede, Lane, \& Surges-
Prokop, 2013); facilitating them in verbal activities: answering questions and asking related questions (Behnam \& Pouriran, 2009; Edens \& Potter, 2013; Knaus, 2013).

According to a study conducted by (Wager, 2013), it shows that a learning design thoroughly planned by the teachers: activities involving the children in math. Not to mention that the teacher's response towards a particular situation that might occur during activities that are not mathematically planned, would give an advantage to those children. It is because they would have more opportunities to be directly involved with mathematical learning; a learning which is rooted in playing-basis. Another study shows that when the teacher builds a playing activity intended to exercise their mathematical ability, it proves to be fruitful when it comes to the upgrading of their arithmetic mentality two times faster than traditional mathematic learning (Kamii, 2014).

Those aforementioned studies highlight the paramount of the importance of the teachers' role in mathematics learning for young learners.

Vygotsky's theoretical framework of sociocultural further strengthens the status and power of teachers in the practice of mathematic learning.

\section{THE ROLE OF TEACHER AND THEORY OF SOCIOCULTURAL IN EARLY CHILDHOOD MATH'S LEARNING PRACTICE}

The theory offered by Vygotsky on sociocultural holds an important role for Early Childhood Education and Development (CED). Mainly, the theory laid a basic framework which focuses on teachers (Dunphy, Dooley, \& Shiel, 2014); also, determines zone of proximal development (ZPD) or known as a person's learning potential (Lerman, 2001; Wortham, 2006); this further facilitates scaffolding or support levels that might change accordingly (Santrock, 2007). Vygotsky assumes all skills and abilities do not determine the children development instead, it determines the potential that they might be unaware of; if they are not under the tutelage of other competent people (Bodrova \& Leong, 2011).

Social interaction is present as a strong point from Vygotsky's theory. It is that the social interaction is perceived as the factor that ignites learning process (Kirch, 2014). Apart from that, in terms of learning constructivist, the learning is seen as a process to improve a better mentality and the ability to master particular instrument (Bodrova \& Leong, 2011). 
Despite having no magical power to create an intellectual function, utterances are important in the development (Levin, 1981 in Renshaw, 1996). In reference to mathematics, by which the concepts are often parts of logic-mathematical knowledge, where at some points, the teachers or adults are able to teach those concepts directly. However, it seems more important for them: teachers and adults, to push their children to think and build mathematicallogical correlations while they are thinking (Kamii, 2016). And the dialogue is one of the media that must be present in that process of math learning.

Kamii gives an example of it: the children learn numbering concepts. The teacher could teach the children to count through tangible objects: cakes or pencils; this because mentioning those numerals would mechanically involve social-conventional knowledge. The naming of the numerals are the ones that have been agreed upon. While in signifying numeral one, two, and three and so on, this involves logic-mathematical knowledge. In that regards, the children should be more involved proactively in their social interaction with their mates and adults. Those people here should be supportive; hence the children's speech and gestures, in which started as social function and communicative, could transform into an internal medium of thinking and problem solving (Renshaw, 1996).

\section{CONCLUSIONS}

In order to provide optimal support to the teachinglearning process, particularly in the learning of mathematics, early childhood teachers should fully understand their role and powers. Because after all, the instructional practices conducted by teachers establish the children's mathematical concepts. However, the forms of support provided by an adult on the math learning through play are limited to their perception of the mathematical concept which they believe (Krummheuer, 2014). Accordingly, further studies to reveal the perceptions of teachers about teaching mathematics to early childhood also need to conduct.

\section{REFERENCES}

Anthony, G., \& Walshaw, M. (2009). Mathematics Education in the Early Years: Building Bridges. Contemporary Issues in Early Childhood, 10(2), 107-122. Doi: 10.2304/ciec.2009.10.2.107
Behnam, B., \& Pouriran, Y. (2009). Classroom Discourse: Analyzing Teacher/Learner Interactions in Iranian EFL Task-Based Classrooms. Porta Linguarium, 12, 117-132.

Bodrova, E., \& Leong, D. J. (2011). Peranti Pikir: Pendekatan Vygotsky pada Pendidikan Anak Usia Dini (S. Narulita, Trans.). In J. L. Roopnarine \& J. E. Jhonson (Eds.), Pendidikan Anak Usia Dini dalam Berbagai Pendekatan (5th ed., pp. 243-264). Jakarta: Kencana.

Brandt, B. (2013). Everyday Pedagogical Practices in Mathematical Play Situations in German “Kindergarten". Educ Stud Math, 84, 227-248. Doi: 10.1007/s10649-013-9490-6

Brendefur, J., Johnson, E. S., Thiede, K. W., Smith, E. V., Strother, S., Severson, H. H., \& Beaulieu, J. (2015). Developing a Comprehensive Mathematical Assessment Tool to Improve Mathematics Intervention for At-Risk Students. International Journal for Research in Learning Disabilities, 2(2), 65-90.

Brendefur, J., Strother, S., Thiede, K., Lane, C., \& Surges-Prokop, M. J. (2013). A Professional Development Program to Improve Math Skills among Preschool Children in Head Start. Early Childhood Education Journal, 41(3), 187-195. Doi: 10.1007/s10643-012-0543-8

Clements, D. H., \& Sarama, J. (2011). Early Childhood Mathematics Intervention. Science, 333(6045), 968-970. Doi: 10.1126/science.1204537

Clements, D. H., \& Sarama, J. (2014a). The importance of the early years. Science, technology \& mathematics, 5-9.

Clements, D. H., \& Sarama, J. (2014b). Learning and Teaching Early Math: The Learning Trajectories Approach. London: Routledge.

Cross, C. T., Woods, T. A., Schweingruber, H. A., National Research, C., \& Committee on Early Childhood, M. (2009). Mathematics Learning in Early Childhood Paths toward Excellence and Equity. From http://site.ebrary.com/id/10355555

Dağl1, Ü. Y., \& Halat, E. (2016). Young Children's Conceptual Understanding of Triangle. Eurasia Journal of Mathematics, Science \& Technology Education, 12(2), 189-202. Doi: 10.12973/eurasia.2016.1398a

Dobbs, J., Doctoroff, G. L., \& Fisher, P. H. (2003). The "Math Is Everywhere" Preschool Mathematics Curriculum. Teaching Children Mathematic, 10(1), 20-22. 
Dunekacke, S., Jenßen, L., \& Blömeke, S. (2015). Effects of Mathematics Content Knowledge on Pre-school Teachers' Performance: a VideoBased Assessment of Perception and Planning Abilities in Informal Learning Situations. International Journal of Science and Mathematics Education, 13(2), 267-286. Doi: 10.1007/s10763-014-9596-z

Dunphy, E., Dooley, T., \& Shiel, G. (2014). Mathematics in Early Childhood and Primary Education (3-8 years).

Edens, K. M., \& Potter, E. F. (2013). An Exploratory Look at the Relationships among Math Skills, Motivational Factors, and Activity Choice. Early Childhood Educ J, 41, 9. Doi: 0.1007/s 10643-012-0540-y

Geary, D. C. (2013). Early Foundations for Mathematics Learning and Their Relations to Learning Disabilities. Current Directions in Psychological Science, 22(1), 23-27. Doi: 10.1177/0963721412469398

Ginsburg, H. P. (2008). Mathematical Play and Playful Mathematics: A Guide for Early Education. 1-38.

. Government Circular No. 1839/C.C2/TU/2009 on the Implementation of Education in Kindergartens and New Student Admission of Elementary School. (2009).

. Government Circular No. 2519/C.C2.1/DU/2015 on the Implementation of Early Childhood Education. (2015).

Haynes, M. (2000). Mathematics education for early childhood: A partnership of two curriculums. Mathematics Teacher Education and Development, 2, 93-104.

K.W., L. (2011). Konsep Matematika untuk Anak Usia Dini. Jakarta: Direktorat Pembinaan Pendidikan Anak Usia Dini Direktorat Jenderal Pendidikan Anak Usia Dini Nonformal dan Informal Kementerian Pendidikan Nasional.

Kamii, C. (2014). Physical Knowledge Activity: Play before the Differentiation of Knowledge into Subjects Learning Across the Early Childhood Curriculum (pp. 57-72).

Kamii, C. (2016). Can Adult Teach Number Concepts to Young Children? Beginning Professional Development Workshop, 59-62.

Kirch, S. A. (2014). Integrating Vygotsky's theory of relational ontology into early childhood science education. Cultural Studies of Science Education, 9(1), 243-254. Doi: $10.1007 / \mathrm{s} 11422-013-9532-5$
Kirkland, L. D., Manning, M., Osaki, K., \& Hicks, D. (2015). Increasing Logic-Mathematical Thinking in Low SES Preschoolers. Journal for Research in Childhood Education, 29(3), 275-286. Doi: 10.1080/02568543.2015.1040901

Knaus, M. (2013). Math is All around You Developing Mathematical Concepts in the Early Years. Albert Park: Teaching Solutions.

Kotsopoulos, D., Makosz, S., Zambrzycka, J., \& McCarthy, K. (2015). The Effects of Different Pedagogical Approaches on the Learning of Length Measurement in Kindergarten. Early Childhood Education Journal, 43, 531-539. Doi: 10.1007/s10643-014-0686-X

Krummheuer, G. (2014). The Relationship between Cultural Expectation and the Local Realization of a Mathematics Learning Environment. In U. Kortenkamp, B. Brandt, C. Benz, G. Krummheuer, S. Ladel \& R. Vogel (Eds.), Early Mathematics Learning: Selected Papers of the POEM 2012 Conference (pp. 71-83). New York, NY: Springer New York.

Lee, J. (2014). Is Children's Informal Knowledge of Mathematics Important? Rethinking Assessment of Children's Knowledge of Mathematics. Contemporary Issues in Early Childhood, 15(3), 293-296. Doi: 10.2304/ciec.2014.15.3.293

Lerman, S. (2001). Cultural, discursive psychology: A sociocultural approach to studying the teaching and learning of mathematics. Educational Studies in Mathematics, 46, 87113.

Mix, K. S., Prather, R. W., Smith, L. B., \& Stockton, J. D. (2014). Young Children's Interpretation of Multidigit Number Names: From Emerging Competence to Mastery. Child Development, 85(3), 1306-1319. Doi: 10.1111/cdev.12197

Newton, K. J., \& Alexander, P. A. (2013). Early Mathematics Learning in Perspective: Eras and Forces of Change. In L. D. English \& J. T. Mulligan (Eds.), Reconceptualizing Early Mathematics Learning (pp. 5-28). Dordrecht: Springer.

Notari-Syverson, A., \& Sadler, F. H. (2008). Math Is for Everyone: Strategies for Supporting Early Mathematical Competencies in Young Children. YOUNG EXCEPTIONAL CHILDREN, 11(3), 15. Doi: $10.1177 / 1096250608314589$ 
Ramos-Christian, V., Schleser, R., \& Varn, M. E. (2008). Math Fluency: Accuracy versus Speed in Preoperational and Concrete Operational First and Second Grade Children. Early Childhood Education Journal, 35(6), 543-549. Doi: 10.1007/s10643-008-0234-7

Renshaw, P. (1996). A Sociocultural View of the Mathematics Education of Young Children. In H. M. Mansfield, N. A. Pateman \& N. Bednarz (Eds.), Mathematics for tomorrow's young children (pp. 59-78). Dordrecht: Springer.

Ruseffendi, E. T. (2006). Pengantar Kepada Membantu Guru Mengembangkan Kompetensinya dalam Pengajaran Matematika untuk Meningkatkan CBSA: Perkembangan Kompetensi Guru (3rd Ed.). Bandung: Tarsito.

Rutunkahu, J. T., \& Kandou, S. (2014). Pembelajaran Maematika bagi Anak Berkesulitan Belajar (R. KR Ed. Vol. 1). Yogyakarta: Ar-ruz Media.

Safitri, M. (2013). Pengaruh Belajar Calistung (Membaca, Menulis, Berhitung) di Usia Dini. Saturday, 5 January 2013. Retrieved 30 October, 2015, from https://www.ibudanbalita.com/diskusi/Pengaru h-Belajar-CALISTUNG-membaca-menulisberhitung-di-usia-dini

Santrock, J. W. (2007). Perkembangan Anak (M. Rahmawati \& A. Kuswanti, Trans. W. Hardani Ed. 11th Ed.). Jakarta: Erlangga.

Scarlatos, L. L. (2006). Tangible math. Interactive Technology and Smart Education, 3(4), 18. Doi: $10.1108 / 17415650680000069$

Stipek, D. (2013). Mathematics in Early Childhood Education: Revolution or Evolution? Early Education \& Development, 24(4), 431-435. Doi: 10.1080/10409289.2013.777285

Suyadi. (2014). Teori Pembelajaran Anak Usia Dini dalam Kajian Neurosains (N. N. Milawati Ed.). Bandung: Remaja Rosdakarya.

Tucker, K. (2013). Mathematics through Play in the Early Years (3rd Ed.). Los Angeles: Sage.

Van Oers, B. (2010). Emergent mathematical thinking in the context of play. Educational Studies in Mathematics, 74(1), 23-37. Doi: 10.1007/s10649-009-9225-X

Varol, F., \& Farran, D. C. (2006). Early Mathematical Growth: How to Support Young Children's Mathematical Development. Early Childhood Education Journal, 33(6), 381-387. Doi: 10.1007/s10643-006-0060-8
Wager, A. A. (2013). Practices that Support Mathematics Learning in a Play-Based Classroom. In L. D. English \& J. T. Mulligan (Eds.), Reconceptualizing Early Mathematics Learning (pp. 163-181). Dordrecht: Springer.

Whitebread, D., \& Coltman, P. (2015). Teaching and learning in the early years: Routledge.

Wortham, S. C. (2006). Early Childhood Curriculum: Developmental Bases for learning and Teaching (J. Peters Ed.). New Jersey: Pearson Merrill Prentice Hall.

Yuwanto, E. (2010, Sunday, 18 July 2010, 21:57 WIB). Balita Diajarkan Calistung, Saat SD Potensi Terkena 'Mental Hectic'. Sunday, 18 July 2010. Retrieved 30 October, 2015, from http://www.republika.co.id/berita/pendidikan/b erita/10/07/18/125274-balita-diajarkancalistung-saat-sd-potensi-terkena-mentalhectic- 